\title{
Data Analysis for Thermal Disease Wearable Devices
}

\author{
Jinkook Kim and Soohyun Kim* \\ Department of Sport and Healthcare, Namseoul University, Korea \\ E-mail:navyjk@daum.net; shkim001@nsu.ac.kr \\ ${ }^{*}$ Corresponding Author
}

Received 29 September 2020; Accepted 31 October 2020;

Publication 15 February 2021

\begin{abstract}
This study was conducted as a planning stage for development of wearable devices capable of managing the thermal diseases by applying the ICT (Information Communication Technology) in an endeavor to meet the urgent needs for countermeasures amid rapid increase in the number of patients with the thermal diseases caused as a result of global warming. The purpose of this study was to provide the basic data for development of wearable devices allowing the patients to be transported expeditiously to hospitals based on synchronization with medical institutions or enabling the prevention of diseases through the response system for each stage according to the reference values based on the data reflecting physical characteristics of individuals by applying the ICT, so that the thermal diseases can be managed effectively. For that, basic study will be conducted on expanding the role of the devices capable of protecting human lives from various thermal diseases caused by the scorching heat waves, which are affecting countries worldwide and expected to persist in the period ahead, by setting the goals of each stage for the thermal disease management platform and collecting necessary information. Based on the accumulated data, the functions of precise diagnosis and treatment can be expected through more accurate evidences pertaining to the thermal diseases.
\end{abstract}

Keywords: Thermal disease, wearable device, service platform, application.

Journal of Web Engineering, Vol. 20_1, 89-102.

doi: 10.13052/jwe1540-9589.2014

(C) 2021 River Publishers 


\section{Introduction}

The increase in average temperature on the surface of the Earth is called 'global warming'. Global temperatures have risen sharply over the last 100 years, and the main culprit for global warming is known to be caused by the increase in the emissions of greenhouse gases. Along with the advancement of industry, the use of fossil fuels has increased rapidly. Furthermore, greenhouse effect has been aggravated gradually as forests are destroyed to increase agricultural production.

Meanwhile, the Korea Meteorological Administration [16] reported that the temperature recently increased by $0.41^{\circ} \mathrm{C}$ per decade in Korea which is affected by the global warming occurring at a speed faster than global average.

In particular, the temperatures soared to the highest recorded level since records began, raising the expectation that the climate regime of summer season would be very likely to change. As those heat waves are expected to occur more frequently in the period ahead, countermeasures should be mapped out in advance [13]. Such evidence is based on the findings that average temperature in summer and winter soared at certain point of time and was maintained at that level, as shown by the results of a joint study between Korea and the United Sates, which analyzed the temperature trends of major cities of the Korean Peninsula over the last 100 years and were published in the International Journal Climatology of the U.K. In other words, the sweltering heat wave is very likely to persist with daily temperature of $40^{\circ} \mathrm{C}$ throughout the summer in the Korean Peninsula, starting from this year.

In the meantime, major cities such as the United States, Japan, and Europe were affected significantly by the scorching heat wave with the temperature rising to $50^{\circ} \mathrm{C}$, leading to death of animals and people, as well as droughts and wildfires, and as a result, the heat wave was classified into a natural disaster. Thus, it is urgent to establish preventive measures against the heat wave.

The data published by the Fire and Disaster Prevention Agency of Japan [10] showed that 125 people died of heat stroke symptoms and 57,534 persons were hospitalized for thermal diseases this summer. In Korea, the Korea Centers for Disease Control and Prevention [15] estimated that there were 3,438 patients with thermal diseases and 42 fatalities nationwide. In particular, approximately $33.1 \%$ (1,137 persons) of the patients were aged 65 or older, which suggests that it would be urgent to take preventive measures amid the nation's transition to aging society.

Usually, temperature-related diseases and deaths can be classified into heat disorders, caused directly by temperature rise, and the exacerbation of 
existing diseases caused due to temperature rise. The human body tends to keep the body temperature constantly at $37^{\circ} \mathrm{C}$, above which the homeostasis can be maintained by body temperature regulation mechanisms of various kinds. However, the exposure to extreme heat wave leads to complete suppression of heat production mechanisms in the body and increases the heat dissipation through skin vascular expansion, sweating, and respiratory stimulation, resulting in the imbalance of the mechanisms of cardiovascular regulation, chemical regulation, and physical regulation. At this time, death is caused by symptoms such as heat stroke, heat exhaustion, heat cramps, heat syncope, etc. Among the main causes of death attributable to exacerbation of existing diseases are included the heart disease, diabetes, hypertension, respiratory disease, accidents and convulsions. For that reason, patients with those diseases are at very high risk [7].

The elderly and young children are the vulnerable populations who may be exposed to those risks. Particularly, various accidents or serious health problems are very likely to occur in those carrying out the types of occupations activities involving outdoor activities even at industrial sites, unless proper preventive measures are followed. Therefore, the establishment of the systems that can help prevent such thermal diseases should be a task to be undertaken at a national level. In connection with such preventive measures, the thermal diseases in the vulnerable population can be prevented drastically if a platform is developed which enables the integrated management for precise measurement of physical conditions, using the wearable devices that converge the Ubiquitous Healthcare technology and wBAN (wireless Body Area Network) capable of collecting the body data [13].

Body information collection devices and applications have already been commercialized in the form of smart bands and smart watches, and recently, the function of measuring the heart rate, blood pressure and stress index using an optical sensor has been added [3]. Moreover, the communication interface is connected to smartphones by mainly using the standardized Bluetooth, Wi-Fi, etc. Through that, the data on individual physical rhythm can be transmitted in real time, and If any risk is detected or persists with alarm warning, fatalities can be minimized based on synchronization with hospitals.

Therefore, this study was intended to provide basic data for building a comprehensive service platform for management of thermal diseases, such as establishment of prediction system using the big data, as well as collection of biometric information with wearable devices and prevention of thermal diseases via wireless communication technology such as smart devices, in order to ensure effective management of the thermal diseases spreading widely over time. 


\section{Device Design Process to Prevent Heat Disease}

The rate of global warning in Korea is faster than global average, resulting in serious consequences. Particularly, the rapid increase in the number of patients with thermal diseases and rising fatalities among the elderly, amid the nation's transition to an aging society, make it imperative to establish countermeasures. Thus, this study was intended to present the basic course for building the service platform enabling efficient management of thermal diseases by applying the ICT (Information Communication Technology) of Korea.

\subsection{Schedule of Study}

This study is planned based on stage 1, stage 2, and stage 3 in overall way as shown in Table 1 below. Specific research and development will be conducted in 4 different areas such as development of wearable devices, development of smartphone application, development of server program, and development of administrator program.

\begin{tabular}{|c|c|c|c|}
\hline & Details of R\&D & Detailed Plans & Remarks \\
\hline \multirow[t]{6}{*}{ Stage 1} & $\begin{array}{l}\text { Development of } \\
\text { wearable device }\end{array}$ & $\begin{array}{l}\text { Selection of sensors, preparation of } \\
\text { specification }\end{array}$ & $\begin{array}{l}\text { Device } \\
\text { specification, } \\
\text { design drawing }\end{array}$ \\
\hline & & $\begin{array}{l}\text { Creation of a prototype of laboratory } \\
\text { level, and communication } \\
\text { synchronization with app } \\
\text { Designing of device }\end{array}$ & \\
\hline & $\begin{array}{l}\text { Development of } \\
\text { smartphone app }\end{array}$ & Preparation of SW design description & $\begin{array}{l}\text { SW design } \\
\text { description }\end{array}$ \\
\hline & & $\begin{array}{l}\text { App sub-module implementation, sensor } \\
\text { communication synchronization }\end{array}$ & \\
\hline & $\begin{array}{l}\text { Development of } \\
\text { server program }\end{array}$ & Preparation of SW design description & $\begin{array}{l}\text { SW design } \\
\text { description }\end{array}$ \\
\hline & & $\begin{array}{l}\text { Literature study on predictive model, } \\
\text { development of algorithm, program } \\
\text { sub-module implementation, app data } \\
\text { collection/analysis }\end{array}$ & \\
\hline
\end{tabular}


Data Analysis for Thermal Disease Wearable Devices

Table 1 Continued

\begin{tabular}{|c|c|c|c|}
\hline & Details of R\&D & Detailed Plans & Remarks \\
\hline \multirow[t]{8}{*}{ Stage 2} & $\begin{array}{l}\text { Development } \\
\text { of wearable } \\
\text { device }\end{array}$ & Production of device, and stability test & $\begin{array}{l}\text { Design drawing, } \\
\text { design description, } \\
\text { production result } \\
\text { report }\end{array}$ \\
\hline & $\begin{array}{l}\text { Development } \\
\text { of } \\
\text { smartphone } \\
\text { app }\end{array}$ & $\begin{array}{l}\text { App sub-module implementation, basic } \\
\text { design }\end{array}$ & $\begin{array}{l}\text { Results of server } \\
\text { synchronization } \\
\text { SW test }\end{array}$ \\
\hline & & $\begin{array}{l}\text { Module integration and app } \\
\text { implementation, detailed design } \\
\text { application }\end{array}$ & \\
\hline & $\begin{array}{l}\text { Development } \\
\text { of server } \\
\text { program }\end{array}$ & $\begin{array}{l}\text { Server sub-module implementation, } \\
\text { data collection/analysis, algorithm } \\
\text { model development } \\
\text { Server module integration and program } \\
\text { implementation, algorithm } \\
\text { improvement }\end{array}$ & \\
\hline & $\begin{array}{l}\text { Development } \\
\text { of } \\
\text { administrator } \\
\text { program }\end{array}$ & $\begin{array}{l}\text { Preparation of administrator program } \\
\text { development, selection of program } \\
\text { basis }\end{array}$ & $\begin{array}{l}\text { SW design } \\
\text { description }\end{array}$ \\
\hline & $\begin{array}{l}\text { Synchronization } \\
\text { test }\end{array}$ & $\begin{array}{l}\text { Preparation of SW design description } \\
\text { Device synchronization, preliminary } \\
\text { test }\end{array}$ & \\
\hline & & Test plan preparation & \\
\hline & & $\begin{array}{l}\text { Integrated synchronization test and } \\
\text { debugging }\end{array}$ & \\
\hline \multirow[t]{5}{*}{ Stage 3} & $\begin{array}{l}\text { Development } \\
\text { of } \\
\text { administrator } \\
\text { program }\end{array}$ & $\begin{array}{l}\text { Sub-module implementation, basic } \\
\text { design }\end{array}$ & $\begin{array}{l}\text { Results of server } \\
\text { synchronization } \\
\text { SW test }\end{array}$ \\
\hline & & $\begin{array}{l}\text { Program implementation through } \\
\text { module integration, detailed design } \\
\text { application }\end{array}$ & \\
\hline & On-site test & $\begin{array}{l}\text { On-site test, platform reliability } \\
\text { verification }\end{array}$ & \\
\hline & & $\begin{array}{l}\text { Improvement of platform and algorithm } \\
\text { through feedback }\end{array}$ & \\
\hline & $\begin{array}{l}\text { Synchronization } \\
\text { test }\end{array}$ & $\begin{array}{l}\text { Integrated synchronization test and } \\
\text { debugging }\end{array}$ & $\begin{array}{l}\text { Results of } \\
\text { integrated test }\end{array}$ \\
\hline
\end{tabular}




\subsection{Research Trends in Korea}

Most of the studies conducted in Korea focused on identifying or predicting the characteristics of patients with thermal diseases caused by heat waves, and there is little study that took an approach from the angle of prevention and management. As disaster prevention is more important than reacting to disaster after its occurrence, it is imperative to conduct studies on building the thermal disease management system and preventing man-made disasters before thermal diseases develop into serious diseases based on prediction of patients with thermal diseases in such a way suited for the climate change in Korea that has witnessed an increase in the frequency of heat waves. The research trends related to thermal diseases in Korea are presented in Table 2 below.

Table 2 Previous studies on thermal disease in Korea

\begin{tabular}{|c|c|c|c|c|}
\hline No & Subject & Year & Author & $\begin{array}{c}\text { Publishing } \\
\text { Organization }\end{array}$ \\
\hline 1 & $\begin{array}{l}\text { Analysis on the characteristics of } \\
\text { patients with thermal diseases in } \\
\text { emergency room, caused due to } \\
\text { heat wave in summer of } 2011\end{array}$ & 2012 & $\begin{array}{l}\text { Jo Soo-Nam, } \\
\text { et al. [12] }\end{array}$ & $\begin{array}{l}\text { Journal of the } \\
\text { Korean Society of } \\
\text { Emergency } \\
\text { Medicine }\end{array}$ \\
\hline 2 & $\begin{array}{l}\text { Effect of climate elements on the } \\
\text { number of patients with thermal } \\
\text { diseases }\end{array}$ & 2016 & $\begin{array}{l}\text { Jeong Da-Eun, } \\
\text { et al. [11] }\end{array}$ & $\begin{array}{l}\text { Journal of Climate } \\
\text { Change Research }\end{array}$ \\
\hline 3 & $\begin{array}{l}\text { Analysis on the causes of } \\
\text { difference among cities in terms of } \\
\text { patients with thermal diseases } \\
\text { caused by high temperature }\end{array}$ & 2015 & $\begin{array}{l}\text { Kim Eun-Byeol, } \\
\text { et al. [2] }\end{array}$ & $\begin{array}{l}\text { Korean } \\
\text { Environmental } \\
\text { Sciences Society }\end{array}$ \\
\hline 4 & $\begin{array}{l}\text { Relation between thermal diseases } \\
\text { in summer and underlying medical } \\
\text { conditions }\end{array}$ & 2016 & $\begin{array}{l}\text { Kim } \\
\text { Si-Heon [1] }\end{array}$ & Ajou University \\
\hline 5 & $\begin{array}{l}\text { Development and establishment of } \\
\text { the system for emergency } \\
\text { room-based active monitoring of } \\
\text { thermal diseases }\end{array}$ & 2014 & $\begin{array}{l}\text { Lee Min-Seong, } \\
\text { et al. [9] }\end{array}$ & $\begin{array}{l}\text { Journal of the } \\
\text { Korean Society of } \\
\text { Emergency } \\
\text { Medicine }\end{array}$ \\
\hline 6 & $\begin{array}{l}\text { Development and pilot application } \\
\text { of the emergency room-based } \\
\text { close surveillance and monitoring } \\
\text { system for severe thermal diseases } \\
\text { in major regions nationwide }\end{array}$ & 2013 & $\begin{array}{l}\text { Song } \\
\text { Seong-Wook, } \\
\text { et al. }[8]\end{array}$ & $\begin{array}{l}\text { Journal of the } \\
\text { Korean Society of } \\
\text { Emergency } \\
\text { Medicine }\end{array}$ \\
\hline
\end{tabular}


Table 2 Continued

\begin{tabular}{llcrl}
\hline No & \multicolumn{1}{c}{ Subject } & Year & Author & \multicolumn{1}{c}{$\begin{array}{l}\text { Publishing } \\
\text { Organization }\end{array}$} \\
\hline 7 & $\begin{array}{l}\text { Study on injury and loss of lives caused } \\
\text { by heat wave by region }\end{array}$ & 2016 & $\begin{array}{l}\text { Park Jae-Eun, } \\
\text { et al. [6] }\end{array}$ & $\begin{array}{l}\text { Journal of The } \\
\text { Korean Society of } \\
\text { Hazard Mitigation }\end{array}$ \\
8 & $\begin{array}{l}\text { Comparative study on predictive model } \\
\text { for fatalities and incidence rate of } \\
\text { thermal disease caused by heat wave }\end{array}$ & 2013 & $\begin{array}{l}\text { Kim Hyeon- } \\
\text { Yeong [5] }\end{array}$ & Ajou University \\
\hline
\end{tabular}

\subsection{Related Domestic and Overseas Markets}

With the advancement of current sensor technology, applications for collecting the body information with miniaturized and diverse wearable devices have been developed. Major products include smart brands (Fitbit, InBody Band, Mi Band, etc.) and smart watches (Galaxy Gear, Apple Watch, etc.), and the main functions consist of activity amount analytical function and sleep analytical function. The market for wearable devices will expand gradually and be combined with various technologies to collect and analyze even more body information.

Thermal disease management service, provided by applying the thermal diseases prevention techniques, is not currently available in Korea. Mostly, most services are intended for safety education, prediction, and analysis of probable patients with thermal diseases. The service related to symptoms of personal abnormalities are said to be slated for release soon in Japan. Thermal diseases caused by heat wave continue to occur, and are more common in the class vulnerable to thermal diseases such as those working outdoors at industrial sites and the elderly, etc. Therefore, a market can be created for the thermal disease and expected to expand gradually.

\subsection{Specific Plan and Goals for Thermal Disease Management Platform}

Specific plan and goals by stage for the thermal disease management platform are as follows.

\subsubsection{Input of information}

Establishment of factors and criteria that define the thermal diseases: Identifying the factors that define the thermal diseases; establishing the criteria; and minimizing the selection to ensure optimization 


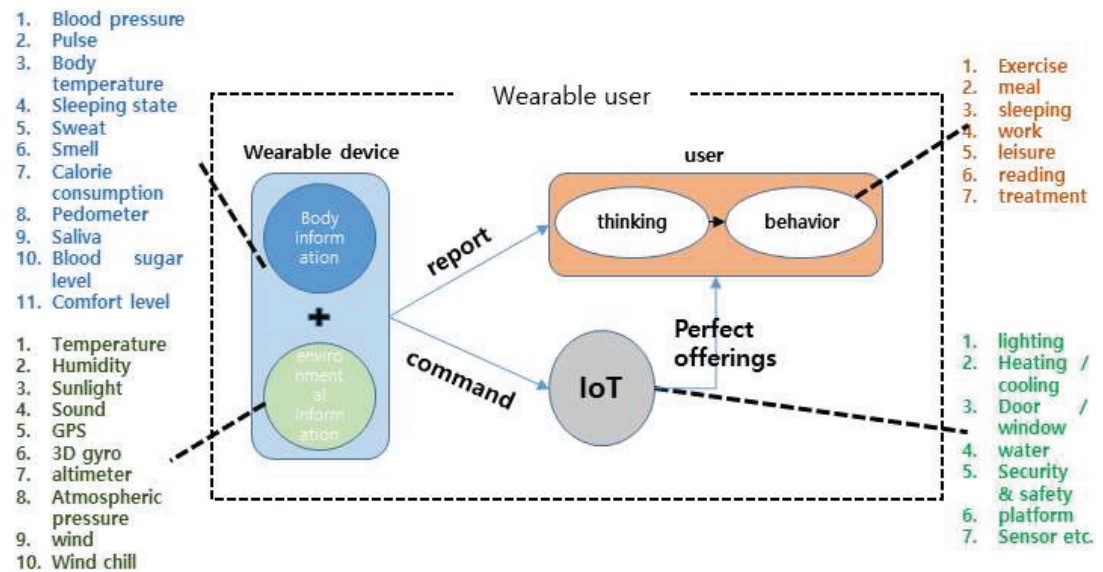

Figure 1 User-centric functional mechanism of smart wearable devices.

(Source: Smart wearable device (approach from the perspective of users), Institute for Information \& communications Technology Promotion, 2014)

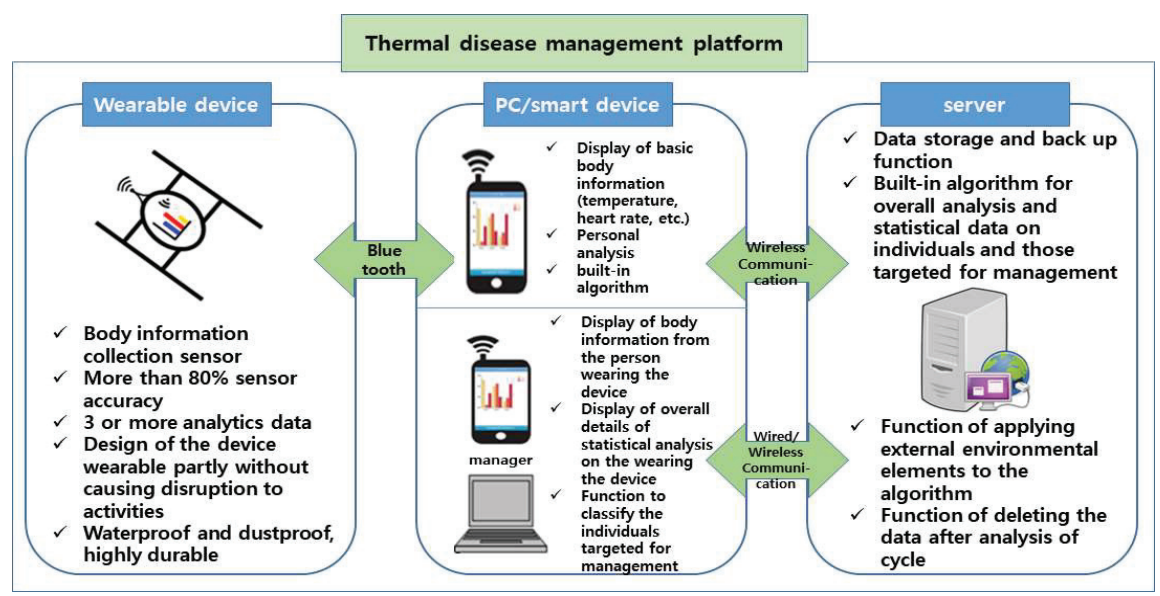

Figure 2 Objectives for development of thermal disease management platform.

- Factors that define the thermal diseases: External air temperature/humidity, body temperature, body water volume, heart rate, blood pressure, etc.

- Examples of standards for warning against the thermal diseases: Warning at simultaneous occurrence of the body temperature $\mathrm{X}^{\circ} \mathrm{C}$ or higher + Heart rate $\mathrm{Y}$ times or higher/minute + External air temperature $\mathrm{X}^{\circ} \mathrm{C}$ or higher 


\subsubsection{Stages for Development of Prototype}

- Stage 1: Select data and sensor to collect by minimizing the factor: Select the sensor that meet the defined requirements for body information collection, and start development of the device.

- Stage 2: Development of device for data collection based on selected sensors: In the initial phase, verify the sensor performance through the test production of laboratory-level devices based on performance-function requirements. Design the wearable devices based on performance-function requirements, durability requirements and other relevant requirements defined after performance verification, and check whether the device to be developed may infringe upon on existing patents, and then establish the measures for avoidance of such infringement or cooperation

- Stage 3: Improve the sensor accuracy of the device for data acquisition: To ensure the reliability of the sensor accuracy of the device, perform the calibration first under the specified conditions and then apply to the device. Enhance the sensor accuracy through sensor calibration and improvement of sensing algorithms. In wearable devices, the sensor accuracy target is more than $80 \%$ initially, and the final target is to ensure accuracy of more than $85 \%$. Synchronize the sensor information with smart device by using the Bluetooth communication module.

- Stage 4: Build the wearable device based on the improved sensor algorithm: Build the wearable device by reviewing the method and design to avoid infringement upon existing patents. Wearable device will be designed to weigh less than $100 \mathrm{~g}$ and provide waterproof/dustproof function.

- Stage 5: Lay the foundation for data collection through sensor devices based on specified factors and criteria: The configuration, which enables collection and analysis of data, is formed by developing the wearable device for data collection, test version smartphone app for acquisition (based on Android 6.0 and higher version) and data server programs (Linux and Windows Server compatible program). SW will be managed systematically by preparing the development documents of software.

- Stage 6: Data collection/analysis and development of algorithm: It will be conducted in conjunction with specialized institutions such as university research laboratories and hospitals, etc., in order to ensure that the specified factor data can be obtained under the controlled test conditions. By selecting the section for each physical condition, the algorithm which redefines the warning section by targets will be developed. The 


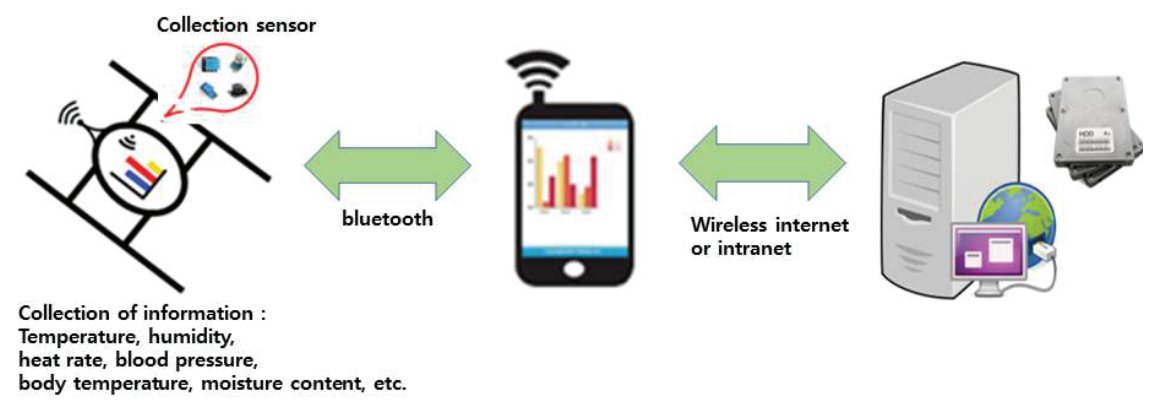

Figure 3 Data collection process.

algorithm model will be researched and developed in such a way that it has maximum simplicity and highest accuracy.

\section{Conclusion \& Suggestions}

This study is a design study for the development of wearable devices that can manage the thermal disease by applying ICT technology at an urgent time as the number of patients with thermal disease increases due to global warming. The purpose of this study is to provide basic data for the development of wearable devices that can prevent diseases through step-by-step response systems based on the standard values, or can quickly transport them through the linkage with medical institutions when a patient occurs, focusing on data reflecting the physical characteristics of individuals using ICT technology. To achieve the purpose of this study, we have designed the design by dividing it into four areas: wearable device development, smartphone application development, server program development, and manager program development. Information collection through sensor and information sharing based on communication technology are the most important technologies. This will be a basic study to expand its role as a device to protect human life from various heat diseases caused by heat waves around the world. Based on the accumulated data, it is also expected that the function of enabling precise diagnosis and processing through more accurate grounds for thermal diseases can be expected.

On the other hand, the limitation in proceeding with this study is that there is no comparison with previous studies as there is no previous study in a similar method as a study to design devices related to thermal diseases. In future studies, it would be good if research proceeds in the direction of 
improving devices or methods that can complement the various functions presented in this study.

\section{Acknowledgements}

Funding for this paper was provided by Namseoul University.

\section{References}

[1] S. H. Kim, 'The relationship between heat illness and pre-existing medical conditions during summer'. Unpublished doctoral dissertation, Ajou University, 2016.

[2] E. B. Kim, Lu, Riyu, J. K. Park, 'Analysis of the causes of difference in the occurrence of thermal patients due to high temperature in large cities'. Proceedings of the Korean Environmental Sciences Society Conference, 24, pp. 77, 2015.

[3] J. W. Kim, S. K. Hong, H. M. Jeong, 'Sensor role and utilization direction in wearable computing environment'. ICT Planning Series of Information and Communication Technology Promotion Center, pp. 1-12, 2016.

[4] H. J. Kim, 'Smart wearable devices: Access from a user's point of view'. Weekly Technology Trends of Information and Communication Technology Promotion Center (October issue), 2014.

[5] H. Y. Kim, 'A comparison of the prediction models for the impact of heat wave on total mortality and incidence of heat-related illness in the republic of Korea'. Unpublished master dissertation, Ajou University, 2013.

[6] J. E. Park, B. Y. Heo, W. Y. Sun, 'A study on human damage due to heat wave by region'. Journal of the Korean Society of Hazard Mitigation, 16(1), pp. 103-109, 2016.

[7] Ministry of Health and Welfare, 'Korea centers for disease control and prevention'. 2018 Heatwave Response Health Care Manual, 2018.

[8] S. W. Song, K. J. Song, K. J. Hong, Y. J. Lee, 'Development and pilot application of an in-depth investigation monitoring system for severe thermal diseases based on emergency rooms by major regions nationwide'. Journal of the Korean Emergency Medical Association, Autumn Conference, pp. 313-314, 2013. 
[9] M. S. Lee, K. J. Hong, S. D. Shin, H. W. Ryu, S. W. Song, Y. J. Lee, K. A. Park, K. S. Lee, 'Development and implementation of emergency department based heat related illness active surveillance system'. The Korean Society of Emergency Medicine, 25(5), pp. 595-601, 2014.

[10] Japan National Emergency Management Agency. www.fdma.go.jp

[11] D. E. Jeong, S. H. Lim, D. W. Kim, W. S. Lee, The effects of climate elements on heat-related illness in South Korea. Journal of Climate Change Research, 7(2), pp. 205-215, 2016.

[12] S. N. Cho, S. H. Kim, S. J. Kim, S. H. Jeong, Y. W. Lee, W. W. Na, J. Y. Jang, K. J. Song, 'Characteristics of summer heatwave victims of emergency department visits in Korea during 2011'. Journal of the Korean Emergency Medical Association, 23(5), pp. 687-695, 2012.

[13] B. S. Choi, 'Wearable device technology and market trends'. S\&T Market Report, 26, pp. 1-22, 2015.

[14] W. S. Choi, C. H. Heo, M. K. Kim, J. W. Kim, H. D. Yoo, J. K. Jeon, J. H. Jeong, 'The warming of the Korean peninsula, a mixture of rapid and linear temperatures'. Journal of Korean Meteorological Society's Academic Conference, pp. 57-58, 2018.

[15] Korea Centers for Disease Control and Prevention. www.cdc.go.kr

[16] Korea Meteorological Administration. www.weather.go.kr

\section{Biographies}

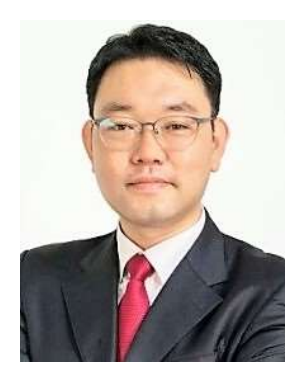

Jinkook Kim received his B.Sc. degrees in Mathematics from The Catholic University of Korea, South Korea and M.Sc. and Ph.D. degrees in Sport Management from Korea University, South Korea. Dr. Kim is currently an adjunct professor at the Department of Sport and Healthcare at Namseoul University. He is interested in sport fusion research and is conducting various related studies. And he is the recipient of the 2011 Korean Society for Sport Management Thesis Award. 


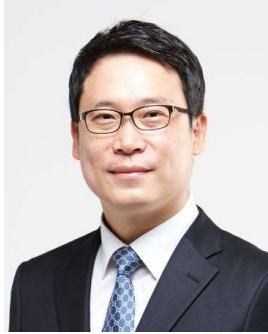

Soohyun Kim received the doctor of philosophy in Sport and Leisure Studies from Yonsei University in 2007. Dr. Kim joined the Sport \& Healthcare department at Namseoul University in 2008. His research interests include Sport Management and Sport Convergence. 
